\title{
Income Divergence between Mexican States in the 1990s: The Role of Skill Premium
}

\author{
ERNESTO AGUAYO-TELLEZ
}

\begin{abstract}
During the period 1940-1985 the variance of average incomes across Mexican states fell by 60 percent. Beginning in 1985, however, and coinciding with the adoption of trade liberalization policies and other market-oriented reforms, state incomes began to diverge. Using microdata from the 1990 and 2000 Mexican Population Censuses, this study decomposes the recent divergence into components due to economy-wide changes in skill prices and components due to state-specific changes in the composition of workers. The study finds that the rise in the education premium hindered the progress of poor states and raised the variance of average state wages and labor earnings. However, educational attainment mostly compensated for this incomewidening effect. State-level regressions reveal that the initial level of education, size of the agricultural sector, and distance from the U.S. border were important factors, while public infrastructure was not. While the border states clearly benefited from increased trade and opening of the economy, I find no evidence that skill demand or the immigration of highly educated workers particularly favored these states.
\end{abstract}

\section{Introduction}

olow's (1956) model predicts that if economies are similar with respect to prefer$\checkmark$ ences and technology, poorer ones will grow faster than richer ones. In other words, there is "economic convergence." Over a period of more than four decades, Mexican states appeared to obey these predictions of long-run convergence. However, coinciding with the adoption of trade liberalization and other domestic reforms, economic convergence across Mexican states broke down starting in the mid-1980s. ${ }^{1}$

This article uses individual data from the 1 percent sample of the 1990 and 2000 Mexican Population Censuses to examine the recent divergence in average incomes across Mexican states. Extensive work has been done previously attempting to explain divergence

Ernesto Aguayo-Téllez is a visiting research fellow in the Center for U.S.-Mexican Studies at the University of California, San Diego. He would like to thank Dr. Chinhui Juhn and Dr. Peter Mieszkowski for their advice and helpful comments. He also thanks three anonymous referees for their very useful comments. He is especially indebted to the referee who suggested extending the analysis of divergence to include the movements of nonwork income. Unfortunately, the results obtained using economic census data produced results that are inconsistent with those obtained for the broader measure of economic activity, gross state product. The author would like to thank CONACYT, the Baker Institute and The Center for US Mexican Studies for financial support.

Submitted February 2005; revised September 2005; accepted January 2006 (c) 2006 Blackwell Publishing, 350 Main Street, Malden MA 02148 US and 9600 Garsington Road, Oxford OX4, 2DQ, UK. 
in gross state product (GSP) between Mexican states. The purpose of this article is to study the role of wages in the recent state divergence in Mexico. The benefits of using microlevel data are twofold. First, by examining labor earnings and self-employment income, rather than state-level output, I come closer to measuring changes in the welfare of a large majority of the population. Second, the microdata allows an assessment of the importance of changes in the composition of workers across states as well as a gauging of the impact of an economy-wide increase in skill premiums. ${ }^{2}$ Using this type of income, I am able to make inferences not obtained by previous research, which relied on aggregated production data. However, labor earnings in Mexico represent only one-third of the total GSP.

To the extent that some states began with significantly lower levels of human capital, one would expect the overall rise in the skill premium to adversely impact those states. The study finds that the rise in skill prices did contribute to the divergence of state incomes. However, state convergence in human capital acquisition has largely counterbalanced the rise in skill prices. While initial educational levels and the rising skill premium were important factors, they are not sufficient to explain the economic divergence across Mexican states in the 1990s. Other demand-related factors appear to have favored the richer states. The reduction of tariffs that protected the agricultural sector led to rapid declines in agricultural employment while trade and foreign direct investment (FDI) spurred by the North American Free Trade Agreement (NAFTA) favored states located close to the U.S. border. Using state labor earnings, I find that the initial level of education, the share of agriculture employment, and distance to the border are important in explaining the divergence, while public infrastructure is not. Results using state product are qualitatively similar to the results using state labor earnings but quantitatively not significant. The study also examines whether the recent divergence is due largely to the rapid growth of the border states. While these states may have benefited from liberalization by attracting more foreign capital, I do not find that skill demand increased more rapidly in this region relative to other regions. Examining migration patterns, there is also little evidence that the border region attracted more human capital relative to other regions. ${ }^{3}$

The rest of the article is organized as follows: the second section reviews the related literature; the third section examines the breakdown in convergence patterns and compares state-level output data with income data from the censuses; the fourth section documents the economy-wide increase in skill premiums and presents the contributions of (skill) price and quantity composition effects; the fifth section reports the results of state-level regressions; and the final section summarizes the conclusions.

\section{Related Literature}

Most studies that examine the recent divergence in state incomes either directly or indirectly emphasize trade liberalization and reforms as a cause. All previous literature used aggregated GSP data and employed the Barro and Sala-i-Martin (1991, 1992) methodology to analyze the convergence-divergence pattern of Mexican states. Using GSP data for 1940-1995, Esquivel (1999) shows a relatively fast convergence process from 1940 to 1960 and a slower or even nonexistent convergence process from 1960 to 1995. Esquivel attributes the lack of convergence during the last decades to the low levels of migration. 
In an earlier article, Mallick and Carayannis (1994) find evidence of stronger convergence in GSP per capita in Mexico from 1970 to 1985 relative to existing estimates of U.S. convergence. Juan-Ramon and Rivera-Batiz (1996) show that the divergence in GSP per capita began before the implementation of the NAFTA. Messmacher (2000) concludes that convergence in GSP per capita ended as the result of economic reforms and their structural effects on the manufacturing sector. Sanchez-Reaza and Rodriguez-Pose (2002) attribute convergence in GSP per capita during the import substitution period (1940-1985) to the discovery of oil reserves in the southern states of Campeche and Tabasco and divergence under the NAFTA (1993-2000) to international market proximity to the U.S., maquiladora investment, and the restructuring of Mexico City.

Chiquiar (2002) argues that economic reforms altered the optimal location choice of manufacturing firms toward the border and that the winners from the structural change of the 1990s were those states initially endowed with, or able to attract, higher levels of human and industrial capital. He finds divergence in GSP per capita even after controlling for differences in stead state levels of output. Esquivel and Messmacher (2002) propose that the divergent process of GSP per capita in the 1990s was driven mostly by differences in labor productivity associated with education and infrastructure. Aroca, Bosch, and Maloney (2003) report that, beyond the group of states bordering the U.S., there is a group of states in which income levels are almost randomly distributed. Therefore, proximity to the U.S. is not an important determinant of high income. Finally, Esquivel et al. (2002) conclude that quality of governance and social instability are factors of equal importance.

\section{Convergence Breakdown}

As shown in previous studies, Mexican states converged during the import substitution period. Figure 1 displays the negative relationship between log GSP per capita in 1940 and the annualized growth rate of GSP per capita from 1940 to $1985 .^{4}$ The negative slope shows that there was economic convergence during this period, with the poorer states growing faster than the richer states.

Since 1985, Mexico has witnessed economic divergence between states. Figure 2 displays the positive relationship between log GSP per capita in 1985 and the annualized growth rate from 1985 to 2000 . A large portion of the gain toward equality that was achieved during the previous forty-five years was lost in a decade.

To formalize the breakdown in convergence, I employ two broadly used indicators of between-state dispersion: $\sigma$-convergence and $\beta$-convergence as discussed in Barro and Sala-i-Martin (1991). $\sigma$-Convergence is achieved when the variance of the natural logarithm of state product per capita (or income per capita) decreases through time. $\beta$-Convergence is defined by the following regression:

$$
\ln \left(Y_{s, t}\right)-\ln \left(Y_{s, t-1}\right)=\alpha+\beta \ln \left(Y_{s, t-1}\right)+\varepsilon_{s}
$$

where $\ln \left(Y_{s, t}\right)-\ln \left(Y_{s, t-1}\right)$ is the change in state product (or income) per capita for state $s$, $Y_{s, t-1}$ is the initial level, and $\varepsilon_{s}$ is the error term. ${ }^{5}$ The sign of the coefficient of the regression associated with the initial level of state product (or income) per capita $(\beta)$ indicates 


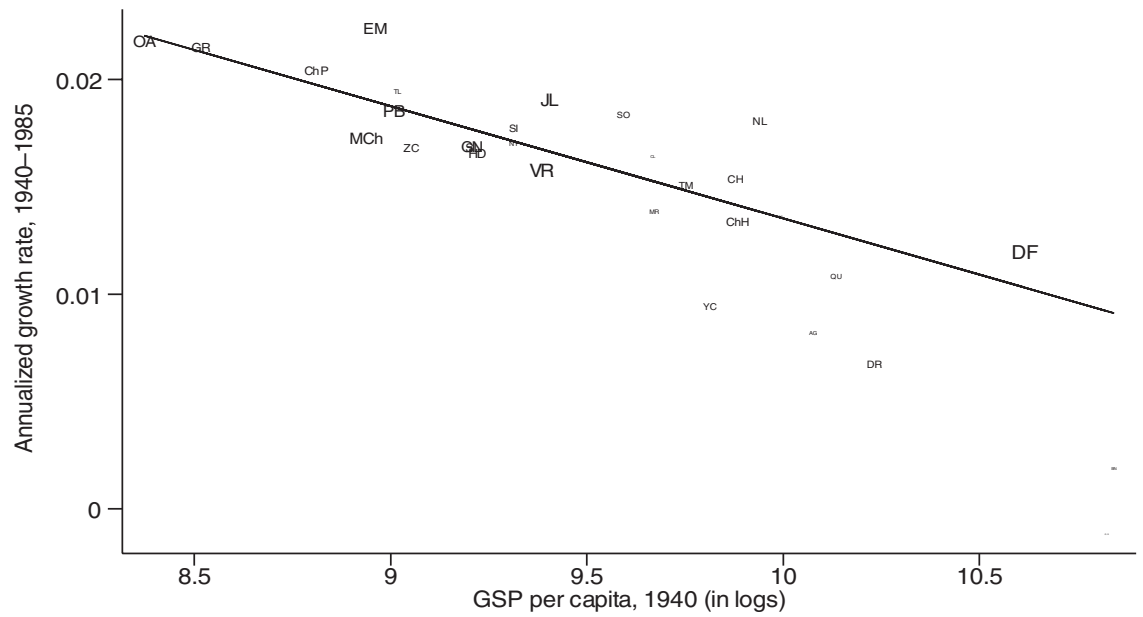

Figure 1. Convergence on GSP PeR CAPITA, 1940-1985.

GSP, gross state product.

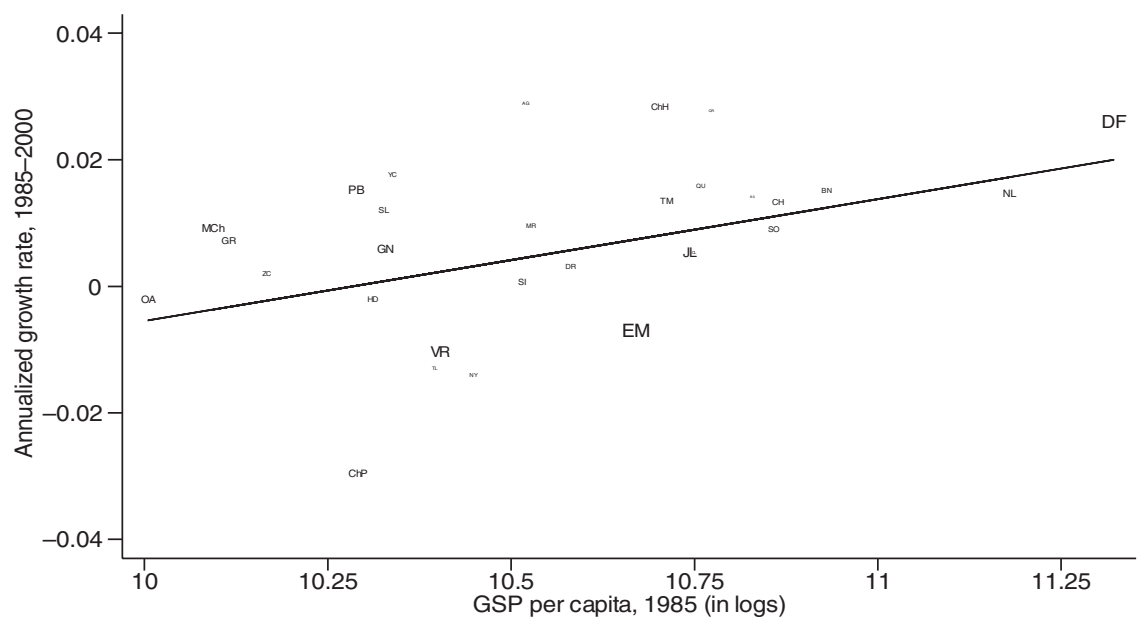

Figure 2. Divergence on GSP PER CAPITA, 1985-2000.

GSP, gross state product.

whether the richer states grew faster (positive) or slower (negative) than the poorer ones.

Table 1 lists the $\sigma$-convergence and $\beta$-convergence estimators for GSP per capita for the convergence period, 1940-1985; the divergence period, 1985-2000; as well as for the 


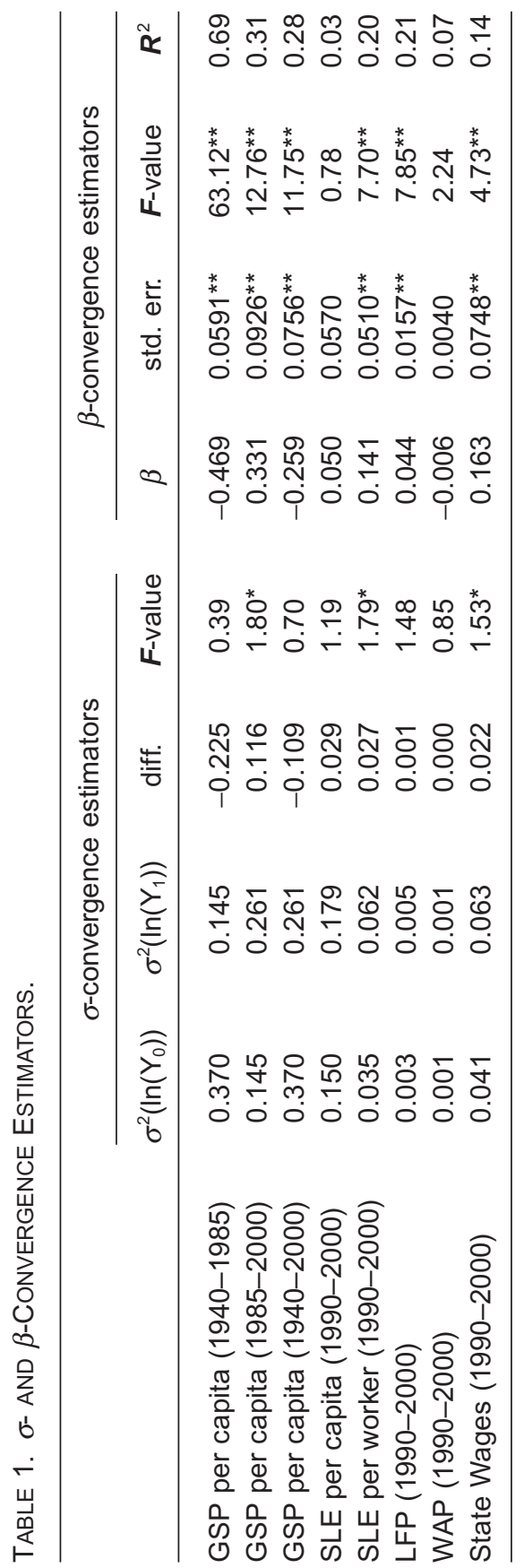

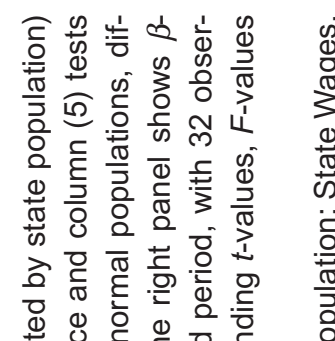

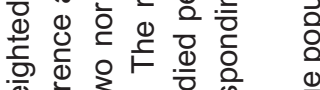

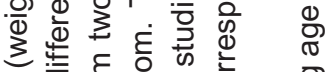
هัర

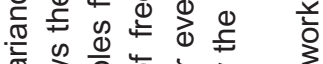

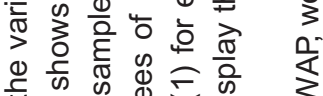
Fै

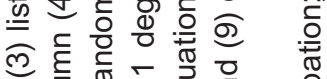

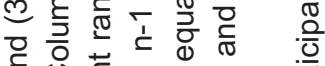
ते 0 专 สิ

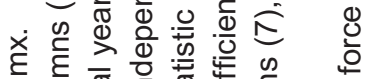

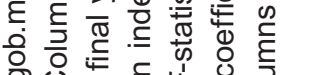

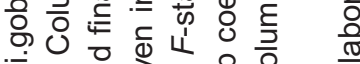
कं

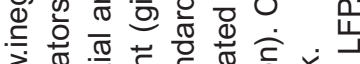

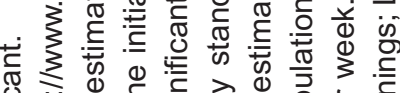
은 원 흘ㄷㄴㅇㅎㅇ응

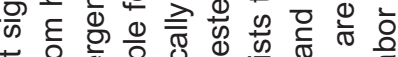

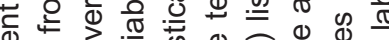
ब 元 당 ब :

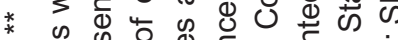
艹 은

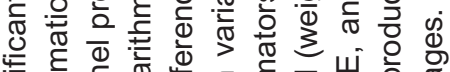

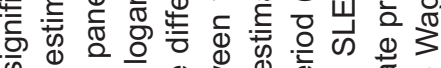
就步 ঠ ญ ৪ 
whole sample period, 1940-2000. The variance of log GSP per capita decreased from 0.37 in 1940 to 0.145 in 1985 , which indicates $\sigma$-convergence. Similarly, the estimates of $\beta$ during the import substitution period are all negative and significant at the 1 percent level. In contrast, during the free-trade period, the variance of log GSP per capita increased from 0.145 in 1985 to 0.261 in 2000 . The $\beta$ estimator for this period is positive $(0.331)$ and statistically significant at the 1 percent level, which indicates $\sigma$ - and $\beta$-divergence.

Gross state product per capita overestimates production in the "oil" states. ${ }^{6}$ In addition, many private enterprises report profits where their office headquarters are located, in this case Mexico City, not where the plants are located. This practice overestimates production in the country's capital. State labor earnings (SLE) per capita and state wages (WAGES) are better estimators of population welfare because wages and self-employment income represent much of the income of the majority of the population in each state.

Income per capita would be a better measure of state wealth because it considers not only labor income but also other sources of income. However, the "Mexican System of National Accounts" does not provide this information at the state level and the Population Census of 1990 did not collect information on any other sources of income except labor income. Labor earnings in Mexico represent only one-third of total income. As a result, the use of population census data will only explain a limited part of the divergence on product between Mexican states. ${ }^{7}$

State labor earnings per capita and state wages can be estimated from the 1 percent sample of the Population Censuses of 1990 and 2000. Mexican Population Census data sets have a similar structure to the Current Population Surveys in the U.S. and contain demographic characteristics such as age, education, and location, as well as labor market outcomes such as activity, labor earnings, hours worked, occupation, and industry. ${ }^{8}$

Table 1 displays the $\sigma$-convergence and the $\beta$-convergence estimators using SLE per capita from 1990 to 2000. State labor earnings per capita as well as GSP per capita present positive $\sigma(0.029$ and 0.116$)$ and $\beta(0.050$ and 0.331$)$ estimates during the free-trade period. ${ }^{9}$ This result is reassuring as both measures are based on two independent data sources: the Mexican System of National Accounts and the Mexican Population Censuses. ${ }^{10}$ However, the results based on SLE per capita are less precise.

In order to understand the sources of SLE per capita divergence, I decompose the changes in SLE per capita $\Delta\left(S L E_{s} / P o p_{s}\right)$ on changes in SLE per worker $\Delta\left(S L E_{s} / W k_{s}\right),{ }^{11}$ changes on state labor force participation $\Delta\left(W k s_{s} / A s l t s_{s}\right)$, and changes on state working age population $\Delta\left(\right.$ Adlts $\left._{s} / P_{o p_{s}}\right)$. Table 1 also shows the $\sigma$-convergence and $\beta$-convergence estimates of the three components of SLE per capita. The variance of log SLE per worker increased 0.027, accounting for most of the rise in variance of SLE per capita (0.029). Labor force participation (LFP) and working age population (WAP) account for trivial portions of the rise in variance of SLE per capita.

Finally, Table 1 presents the $\sigma$-convergence and the $\beta$-convergence estimators for an alternative measure: Average State Wages, which are defined as labor earnings divided by hours worked. As GSP per capita, SLE per capita, and SLE per worker, State Wages diverged across states during the trade-liberalization period. The following analysis focuses 
on weekly SLE per worker and hourly state wages, which accounted for most of the divergence.

\section{Rising Skill Prices and Education-Decomposition Analysis}

Skill prices. After trade liberalization and domestic reforms, the wages of skilled workers increased relative to wages of unskilled workers in Mexico. During the import substitution period, Mexico followed policies that protected low-skilled labor. As the literature commonly suggests, economic liberalization and domestic reforms in Mexico lead to an increase in skill demand in the economy. ${ }^{12}$

How would an increase in skill prices impact regional convergence patterns? To the extent that poorer regions began the decade significantly lagging in education and skill levels, one would expect the economy-wide increase in skill prices to contribute to divergence.

The following Mincerian wage equation was used to examine changes in skill prices:

$$
\ln \left(Y_{i, t}\right)=\gamma_{t}^{0}+\gamma_{t}^{E D U} E D U_{i, t}+\gamma_{t}^{E X P} E X P_{i, t}+\gamma_{t}^{E X P^{2}} E X P_{i, t}^{2}+\gamma_{t}^{G E N} G E N_{i, t}+v_{i, t}
$$

where $E D U_{i, t}$ is years of schooling, $E X P_{i, t}$ and $E X P_{i, t}^{2}$ are years of potential experience and its square, and $G E N_{i, t}$ is a dummy variable for gender.

I estimated the above equation separately for 1990 and 2000, using both log hourly wages and log weekly earnings as the dependent variables. Table 2 reports the results. In 1990 , every additional year of education increased wages by 8.5 percent. In 2000, the education return had increased to 10.6 percent. Estimates of the experience premium also increased during the decade while the male premium fell slightly.

State-specific changes in skill quantities. From 1990 to 2000, average education increased from 6.7 to 7.9 years and its standard deviation decreased from 4.5 to 4.4 years, implying compression in the distribution of education across individuals. Richer states have much higher education levels than poorer states. In 1990, the average education level of a worker in the richest state, Baja California Norte, was 8.4 years and the average education level of a worker in the poorest state, Chiapas, was 5.3 years. However, states with the lower wages had the largest increases in educational attainment from 1990 to 2000, implying convergence in workers' education across Mexican states. ${ }^{13}$ Table 3 shows the $\sigma$ - and $\beta$-convergence estimates for mean education levels across states. Its variance decreased 36 percent from 1.24 in 1990 to 0.786 in 2000. Similarly, the education $\beta$ convergence estimate is negative and significant $(-1.204){ }^{14}$

Experience levels are also converging as confirmed statistically in Table 3. Experience levels are growing more rapidly in the richer states, which have had historically lower levels of experience. The distribution of male work force across states is similar to the distribution of experience. Poorer states have higher rates of male labor force participation, but these differences decreased during the last decade. Table 3 indicates $\sigma$ - and $\beta$ convergence based on workers' gender composition. ${ }^{15}$

Wage decomposition analysis. Next, I build on the work of Juhn, Murphy, and Pierce (1993) and Blau and Kahn (1997) on relative wage gaps to decompose changes in income 


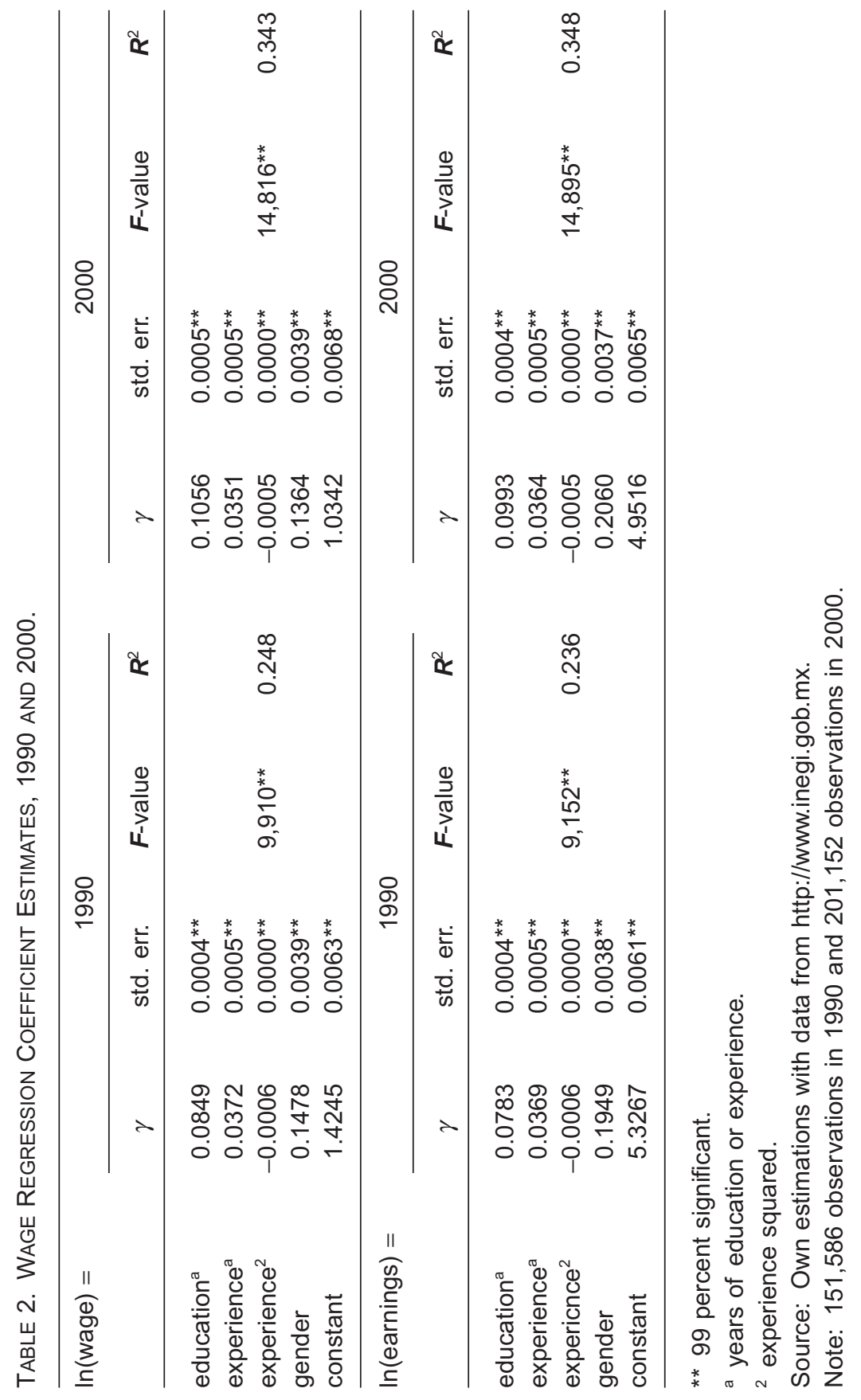




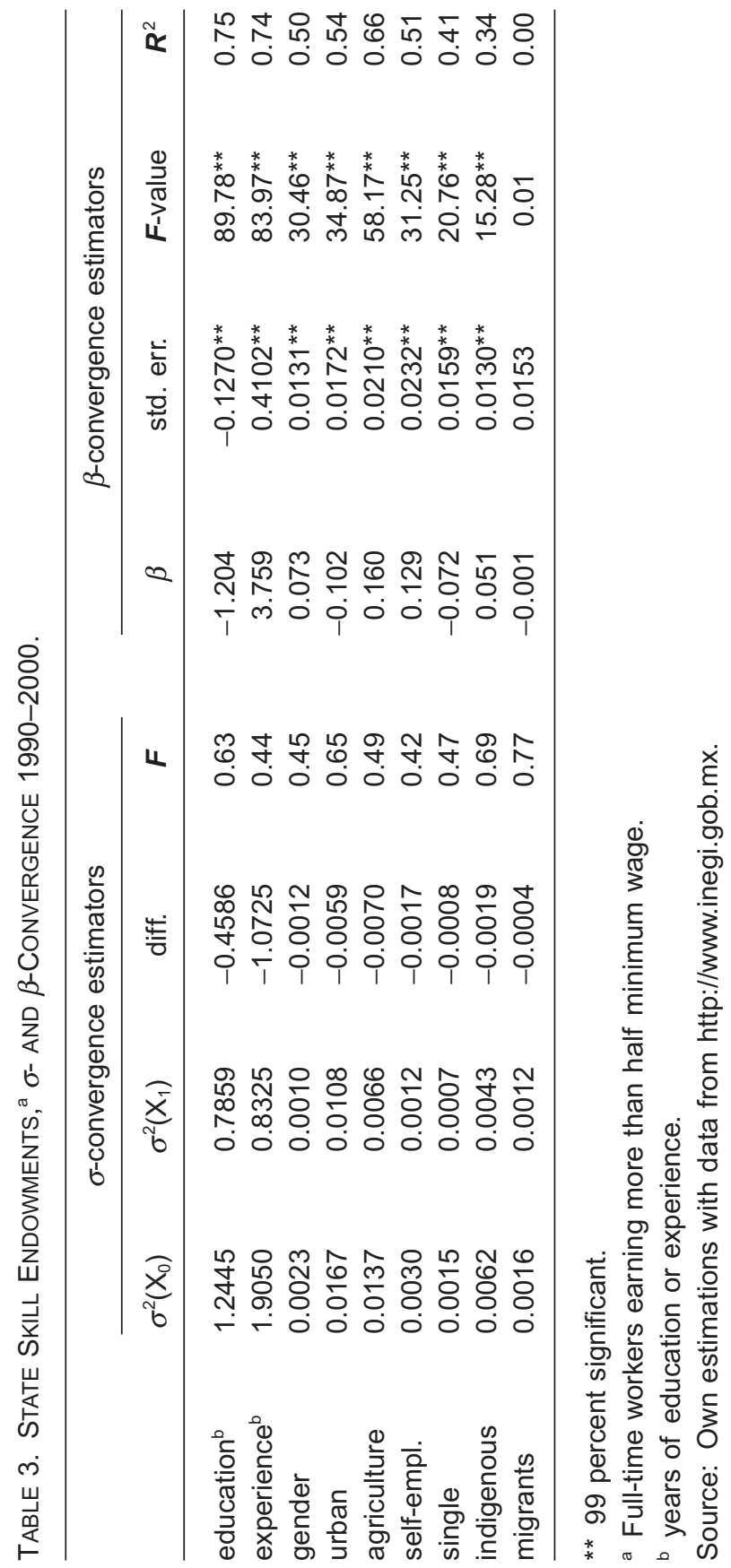


differentials into economy-wide factors and "state-specific" factors. I decompose the change in variance of incomes across states into a component due to the rise in skill prices (the price effect) and a component due to state-specific changes in education and other characteristics (the quantity effect). The following earnings equation is specified:

$$
\ln \left(Y_{i s, t}\right)=\gamma_{t} X_{i s, t}+v_{i s, t}
$$

where $Y_{i s, t}$ is the hourly wage (or weekly labor earnings) of individual $i$ in state $s$ at time t, $X_{i s, t}$ is a vector of individual characteristics usually associated with skill, $\gamma_{t}$ is a vector of prices, and $v_{i s, t}$ is the error term. In fact, I use the Mincerian specification laid out in equation (2). The difference in state average wages between year 1 and year 0 can be written as:

$$
\ln \left(Y_{s, 1}\right)-\ln \left(Y_{s, 0}\right)=\gamma_{1} X_{s, 1}-\gamma_{0} X_{s, 0}+\left(v_{s, 1}-v_{s, 0}\right)
$$

Rearranging terms, one has the following:

$$
\ln \left(Y_{s, 1}\right)-\ln \left(Y_{s, 0}\right)=\left(\gamma_{1}-\gamma_{0}\right) X_{s, 0}+\gamma_{1}\left(X_{s, 1}-X_{s, 0}\right)+\left(v_{s, 1}-v_{s, 0}\right)
$$

Changes in state wages, $\ln \left(Y_{s, 1}\right)-\ln \left(Y_{s, 0}\right)$, can be decomposed into three parts: (1) changes in skill prices, $\left(\gamma_{1}-\gamma_{0}\right) X_{s, 0} ;$ (2) changes in the quantities of skills, $\gamma_{1}\left(X_{s, 1}-X_{s, 0}\right)$; and (3) changes in the residuals, $\left(v_{s, 1}-v_{s, 0}\right) .{ }^{16}$

To make this decomposition operational, construct counterfactual state-level wages. Wages are first predicted in 2000, keeping the distribution of skill endowments $\left(X_{s}\right)$ and state residuals $\left(v_{s}\right)$ fixed at 1990 levels, but allowing skill prices $(\gamma)$ to vary, as in the following:

$$
\ln \left(Y_{s, 00}^{P}\right)=\ln \left(Y_{s, 90}\right)+\left(\gamma_{00}-\gamma_{90}\right) X_{s, 90} .
$$

Equivalently, substituting $\ln \left(Y_{s, 90}\right)$ with $\gamma_{90} X_{s, 90}+v_{s, 90}$,

$$
\ln \left(Y_{s, 00}^{P}\right)=\gamma_{00} X_{s, 90}+v_{s, 90} .
$$

Equations (6) and (6a) predict wages in 2000, allowing only skill premiums to vary. If one allows both observable prices $(\gamma)$ and state skill endowments $\left(X_{s}\right)$ to change to 2000 levels but keeps the distribution of state residuals $\left(v_{s}\right)$ fixed at 1990 levels, wages in 2000 would be defined by:

$$
\begin{gathered}
\ln \left(Y_{s, 00}^{P Q}\right)=\ln \left(Y_{s, 90}\right)+\gamma_{00}\left(X_{s, 00}-X_{s, 90}\right)+\left(\gamma_{00}-\gamma_{90}\right) X_{s, 90} \\
\text { or } \quad \ln \left(Y_{s, 00}^{P Q}\right)=\gamma_{00} X_{s, 00}+v_{s, 90}
\end{gathered}
$$

Finally, if one allows observable prices $(\gamma)$ and state skill endowments $\left(X_{s}\right)$ and the distribution of the residuals to change to 2000 levels, one obtains:

$$
\ln \left(Y_{s, 00}^{P Q R}\right)=\ln \left(Y_{s, 90}\right)+\gamma_{00}\left(X_{s, 00}-X_{s, 90}\right)+\left(\gamma_{00}-\gamma_{90}\right) X_{s, 90}+\left(v_{00}-v_{90}\right)
$$




$$
\text { or } \quad \ln \left(Y_{s, 00}^{P Q R}\right)=\gamma_{00} X_{s, 00}+v_{s, 00}
$$

which replicates the actual wage distribution in 2000 .

Having the estimated values of the skill premium in 1990 and $2000\left(\hat{\gamma}_{90}\right.$ and $\left.\hat{\gamma}_{00}\right)$, the estimated state average residuals $\left(\hat{v}_{s, 90}\right.$ and $\left.\hat{v}_{s, 00}\right)$, and the observed 1990 and 2000 state skill endowments $\left(X_{s, 90}\right.$ and $\left.X_{s, 00}\right)$ I can estimate the values of $\ln \left(\hat{Y}_{s, 00}^{P}\right), \ln \left(\hat{Y}_{s, 00}^{P Q}\right)$, and $\ln \left(\hat{Y}_{s, 00}^{P Q R}\right)$ for every state of Mexico. The technique is to attribute the change in state inequality in $\ln \left(\hat{Y}_{s, 00}^{P}\right)$ to changes in skill prices, then attribute any additional change in state inequality in $\ln \left(\hat{Y}_{s, 00}^{P Q}\right)$ to changes in state skill endowments, and finally to attribute any additional change in state inequality for $\ln \left(\hat{Y}_{s, 00}^{P Q R}\right)$ beyond those found for $\ln \left(\hat{Y}_{s, 00}^{P Q}\right)$ to changes in the distribution of the residuals. ${ }^{17}$

Table 4 lists the decomposition results for wages and SLE per worker. The variance of state wages increased $0.022 \log$ points from 1990 to 2000 . The variance of $\ln \left(\hat{Y}_{s, 00}^{P}\right)$, allowing only skill prices to change, increased by 0.009 , accounting for 41 percent of the increase in the variance of state wages. The variance of $\ln \left(\hat{Y}_{s, 00}^{P Q}\right)$, allowing both skill prices and skill state quantities to change, increased by 0.002 . Therefore, attributing any additional change in state inequality in $\ln \left(\hat{Y}_{s, 00}^{P Q}\right)$ over $\ln \left(\hat{Y}_{s, 00}^{P}\right)$ to changes in state skill endowments, inequality in the distribution of skill quantities across states decreased by 0.007 , accounting for a 32 percent reduction in the variance of wages. As the two effects move in opposite directions, prices and quantities together account for 9 percent of the rise in the variance of state wages. State inequalities explained by changes in the distribution of the residuals increased by 0.020 , which equals 91 percent of the increase in the variance of state wages. Similar results are obtained when one examines the SLE per worker. One way to interpret these findings is that if skill levels had not converged across states during 1990 to 2000 , divergence in state incomes would have been even larger. ${ }^{18}$

I also study the effects of changes in prices and quantities of skills by means of the $\beta$ convergence framework. Table 5 displays the $\beta$-estimators of regressing the price effect, $\left(\gamma_{00}-\gamma_{90}\right) X_{s, 90}$, the quantity effect, $\gamma_{00}\left(X_{s, 00}-X_{s, 90}\right)$, and the residual effect, $\left(v_{s, 00}-v_{s, 90}\right)$ against initial 1990 state wage and SLE per worker. The $\beta$-estimate of the combined skills price and quantity effect is positive for state wages (0.0189) as well as for SLE pw (0.0277), which means that the combined effect of changes on prices and quantities of skills generated divergence across Mexican states. The positive $\beta$-estimate for the skills price effect ( 0.0975 for wages and 0.0987 for SLE pw) indicates that changes in skill prices contributed to state divergence. The $\beta$-estimate of the quantity effect is negative $(-0.0786$ for wages and -0.0719 for SLE $\mathrm{pw})$, indicating state convergence. The $\beta$-convergence results are similar to the $\sigma$-convergence results.

\section{Absolute and Conditional Divergence: State-Level Regressions}

Per capita wages across states diverged in Mexico during the 1990s even after controlling for changes in the returns to skill, and for changes in the distribution of skills across states. The $\beta$-convergence between Mexican states fails when assuming identical preferences and technology across states. This does not mean that neoclassical models are 


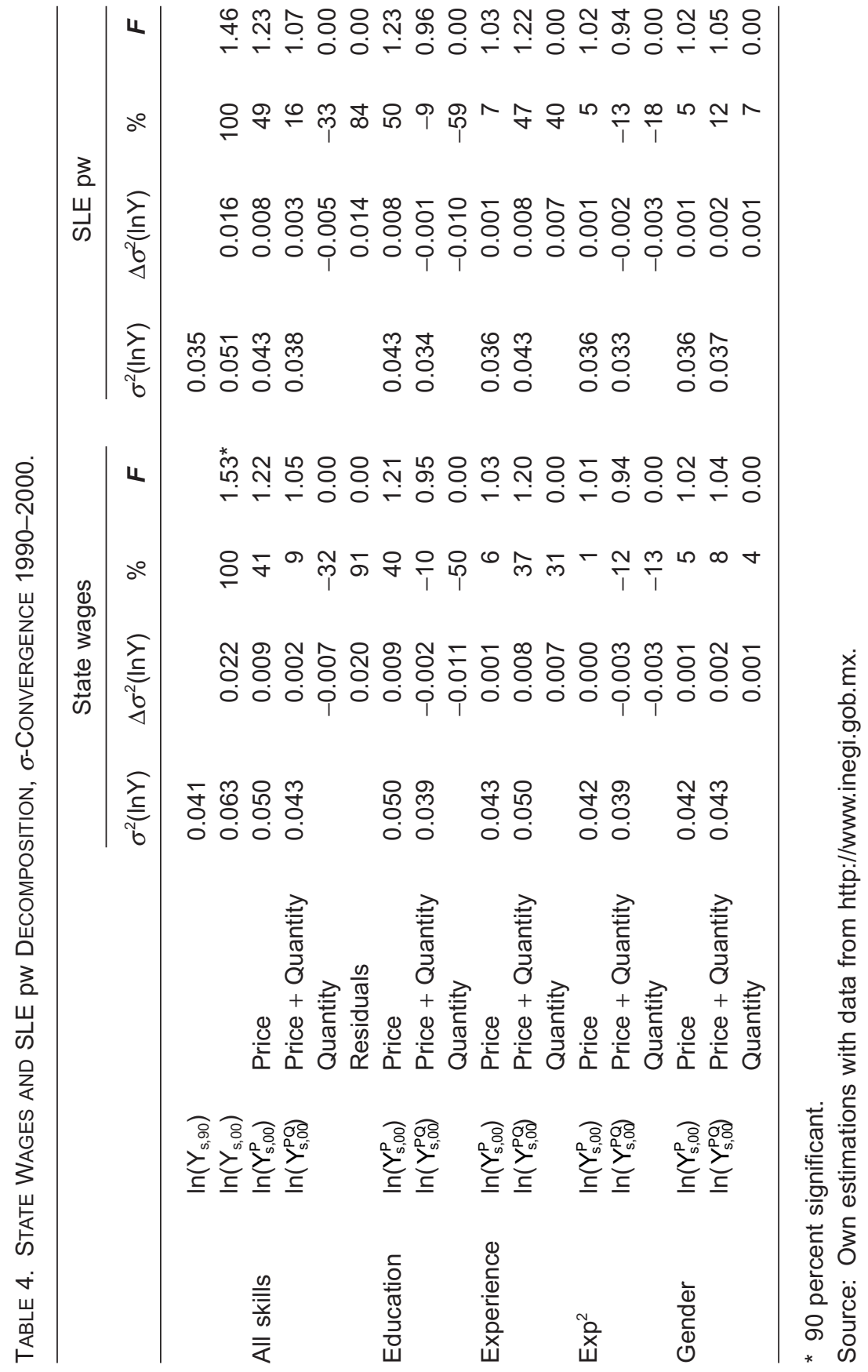




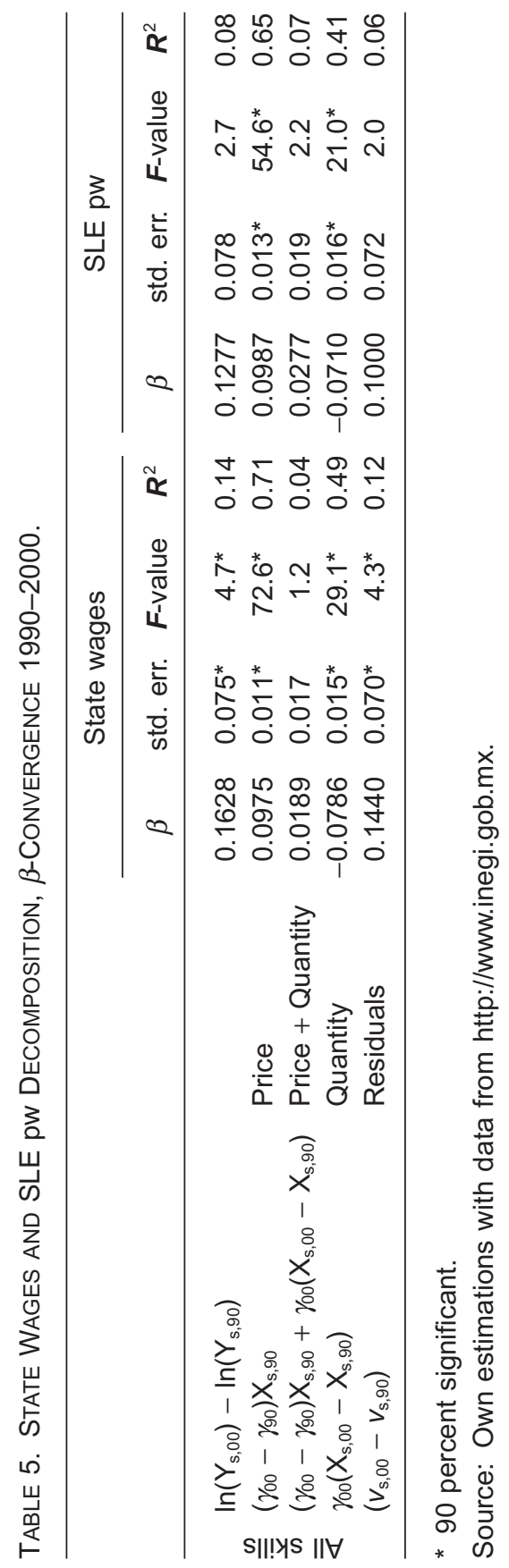


wrong; it is just that it was incorrectly assumed that Mexican states are similar. In a situation in which different countries or regions differ in terms of their steady state per capita income levels, Solow's model (1956) predicts conditional $\beta$-convergence. If economies are not similar, conditional convergence indicates that the economies farther from their own steady states grow faster. This section applies the Barro and Sala-i-Martin (1991) methodology to inquire into the reasons for the divergence between Mexican states.

Define the average growth rate of product (or income) per capita of state $s\left(Y_{s}\right)$ over the time interval between periods $\mathrm{t}=0$ and $\mathrm{t}=T$ as follows:

$$
\frac{1}{T} \log \left(\frac{Y_{s, T}}{Y_{s, 0}}\right)=x_{s}+\frac{1-e^{-B T}}{T} \cdot \log \left(\frac{Y_{s}^{*}}{Y_{s, 0}}\right)
$$

where the parameter $B$ governs the speed of the adjustment to the steady state. $x_{s}$ is the technology level of state $s$ and $Y_{s}^{*}$ is the steady state level of product (or income) per capita of state $s$. Multiplying by $T$, and solving the logarithms, equation (9) can be expressed as follows:

$$
\log \left(Y_{s, T}\right)-\log \left(Y_{s, 0}\right)=x_{s} T+\left(1-e^{-B T}\right) \cdot \log \left(Y_{s}^{*}\right)-\left(1-e^{-B T}\right) \log \left(Y_{s, 0}\right)
$$

Assuming similar steady states $\left(Y_{s}^{*}=Y^{*}\right)$ and technology $\left(x_{s}=x\right)$, substituting $\alpha=x T$ $+\left(1-e^{-B T}\right) \cdot \log \left(Y^{*}\right)$ and $\beta=-\left(1-e^{-B T}\right)$, and adding a random disturbance $\left(\varepsilon_{s}\right)$, equation (10) can be written as:

$$
\log \left(Y_{s, T}\right)-\log \left(Y_{s, 0}\right)=\alpha+\beta \log \left(Y_{s, 0}\right)+\varepsilon_{s}
$$

which is nothing but equation (1).

Considering unequal states, with different steady states of product (or income) per capita and different levels of technology, equation (10) must be analyzed with state specific values of $x_{s}$ and $Y_{s}^{*}$. The problem is that one cannot predict the steady state levels. Barro and Sala-i-Martin's (1991) solution is to include other state variables $\left(X_{s}\right)$ to approximate the steady state values.

Defining $\phi X_{s}=x_{s} T+\left(1-e^{-B T}\right) \cdot \log \left(Y_{s}^{*}\right)$ and $\beta=-\left(1-e^{-B T}\right)$, and adding an error term $\left(\varepsilon_{s}\right)$, equation (10) is modified as follows:

$$
\log \left(Y_{s, T}\right)-\log \left(Y_{s, 0}\right)=\alpha+\phi X_{s}+\beta \log \left(Y_{s, 0}\right)+\varepsilon_{s}
$$

After controlling for differences in steady states and technology, the value of $\beta$, the convergence coefficient, must be negative, indicating conditional convergence.

State-level regressions. The initial stock of human capital may influence the rate of introduction of new technologies and ideas. I proxy a state's initial level of human capital by two variables, the mean level of education of the adult population in 1990 (EDU90), and the number of elementary schools for every thousand inhabitants in 1990 (ELEM90). Similar considerations lead to the inclusion of a measure of the initial level of public infrastructure. The availability of transportation and a developed communications system in a state is expected to facilitate growth and to attract foreign investment. Two measures of 
state infrastructure availability are included: the number of telephone lines per capita in 1990 (TELS90) and the number of airports for every thousand inhabitants in 1990 (AIRP90).

The distance from the U.S. border (DISTB) is included to reflect the innate advantage of being closer to Mexico's major trading partner. A second variable related to Mexico's growing economic interdependence with the U.S. which may affect the growth of different states is FDI per capita in 1994 (FDI94). ${ }^{19}$ The initial share of agricultural employment in a state (AGREMP90) allows for the possibility that states intensive in the production of agricultural commodities will experience slower growth in wages, especially as the NAFTA liberalized trade in agricultural commodities while economic restructuring decreased agriculture subsidies.

I estimated equation (12) for state wages and GSP using the independent variables discussed previously. Table 6 lists the results. Column (1) displays the estimated $\beta$-coefficient for the initial level of wages (lnWAGE90) without adding any other independent variable. This is the $\beta$-estimate presented in the last panel of Table 1 . Its positive $(0.1628)$ and significant value implies absolute $\beta$-divergence in state wages.

Column (2) reports the results when four variables are added to the regression: EDU90, ELEM90, TELS90, and AIRP90. The sign of the estimated coefficient for lnWAGE90 is small and is not significantly different from zero. EDU90 is positive and significant, implying that the initially more educated states grew faster. The three infrastructure variables (ELEM90, TELS90, and AIRP90) are positive but not statistically significant.

Column (3) shows the results for three independent variables closely related to trade liberalization: FDI94, DISTB, and AGREM90. For this specification, the sign of the initial value of lnWAGE90 is negative and significant, implying conditional convergence in state wages. The three independent variables are significant and have the correct sign. States that are closer to the U.S. border, receive larger amounts of FDI, and have smaller shares of agricultural employment grew faster.

Column (4) combines all of the explanatory variables included in regressions 2 and 3. This regression also implies conditional convergence of wages as the coefficient of lnWAGE90 is negative and significant. Also, the coefficients for DISTB and AGREMP90 remain qualitatively the same and quantitatively quite similar. However, the coefficients FDI94 and EDU90 become negative. The three infrastructure variables have the expected positive signs but are statistically insignificant. These results indicate that FDI and the infrastructure variables are highly correlated and that it is impossible to disentangle the separate effects of these factors.

Columns (5), (6), and (7) replicate the models of columns (2), (3), and (4) using GSP from 1993 to 2000 . Results using GSP data are qualitatively similar to the results using state wages but quantitatively weaker. The lack of data in state profits does not allow one to observe the precise contribution of work and nonwork income on divergence in Mexico. However, state-level regressions on GSP and wages suggest that profits may contribute to divergence in the same way as wages and variables such as distance to the border, 


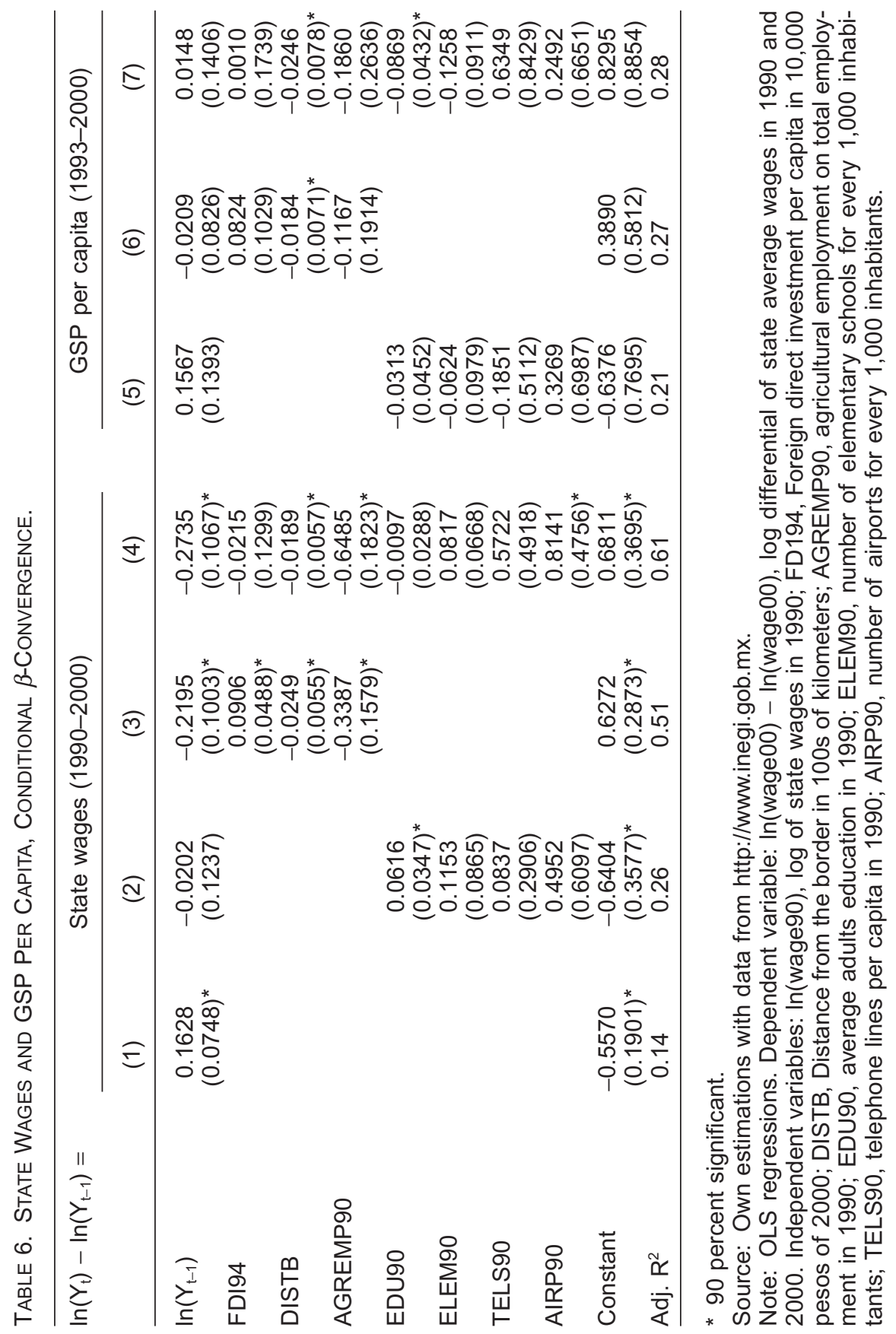


agriculture employment, and the initial level of education are the source of total income divergence between Mexican states.

A border story. The state-level results are now used to explain how state-level factors such as international trade, agricultural employment, and FDI affected divergence during the last decade in Mexico. Trade liberalization and domestic reforms decreased domestic agricultural prices and investment. The reductions of import tariffs and quotas on agricultural goods, and the virtual dismantle of subsidies and public credits negatively impacted agricultural revenues. The share of employment in agriculture fell from 15 percent in 1990 to 10 percent in 2000. Real wages in this sector decreased by 3.4 percent a year while real wages at the national level decreased only by 1.6 percent a year. Hence, it is expected that states specialized in agricultural production declined absolutely and relatively between 1990 and 2000 .

The elimination of trade restrictions and foreign investment controls in Mexico and the economic boom in the U.S. greatly increased trade between the two countries and resulted in a substantial raise in FDI in Mexico. From 1994 to 2000, FDI increased by 7.5 percent a year while international trade grew by 16.3 percent a year. ${ }^{20}$ The six northern border states received a disproportionate share of the increased level of FDI, much of it in the maquiladora sector. ${ }^{21}$ All workers in the richer northern states, close to the U.S. market, did relatively well as a result of the export boom, the increase in FDI inflows, and the general prosperity in the U.S. during the 1990s. The share of manufacturing employment in the border region increased by 4.2 percentage points between 1990 and 2000, while in the Federal District and its metropolitan area, this share decreased by 7.3 percentage points.

There is some theoretical and empirical support for the new economic geography of Mexico. Krugman and Elizondo (1996) argue that during the import substitution period, 1945-1985, manufacturers who produced for a relatively small domestic market in Mexico found it advantageous to locate close to the main source of final demand, Central Mexico. Once free trade is introduced and firms begin buying foreign inputs and selling to the U.S., transportation cost considerations will lead manufactures to move northward away from Mexico City's manufacturing belt.

It is also postulated that since FDI is complementary with skilled labor, the skill premium will increase in northern states relative to other states. Hanson $(1997,1998)$ and Hanson and Harrison (1999) documented for the 1980s the relatively large increase in the wage of white-collar workers in the border states and used wage surveys of manufacturers to link these wage increases to FDI. Feenstra and Hanson (1997) provide empirical evidence that FDI may explain about 50 percent of the increase in the share of skilled wages in the northern states during the 1980s. Airola and Juhn (2003) use the Mexican Household Income and Expenditure Survey, for the period 1984-2000, to confirm that the returns to skill increased sharply from 1984-1994. They find that the trend in inequality slowed since 1994, a period during which FDI and trade increased. Thus, they are skeptical that the rise in inequality in the 1990s was caused largely by FDI and outsourcing.

As noted previously, from 1990 to 2000, wages for skilled workers increased relative to wages for unskilled workers; but this increase was not larger at the border region, which 


\section{GROWTH AND CHANGE, JUNE 2006}

has experienced a relatively larger inflow of FDI. At the national level, the wage bill share of workers with twelve years of schooling or more increased by 12 percentage points (from 36.9 percent in 1990 to 48.9 percent in 2000). At the border region, this wage bill share increased by only 8.7 percentage points (from 39.4 percent in 1990 to 48.1 percent in 2000). ${ }^{22}$ In addition, there is no evidence that the border region attracted more highly educated workers relative to other regions. Even though one observes a relatively large inflow of migrants to the border region, ${ }^{23}$ these migrants were less educated ( 8.5 years) than border workers ( 9.2 years) and even less educated than the average worker in Mexico (8.7 years) in 2000. While there is no question that wages of all workers are increasing at the border relative to other states, there is no evidence that the relative demand of skilled workers increased rapidly in this region. ${ }^{24}$

\section{Conclusions}

Trade and domestic policies implemented in Mexico during the last two decades of the twentieth century increased wages of skilled workers relative to wages of unskilled workers. At the same time, richer states were relatively abundant in skilled workers. The economy-wide increase in the skill premium and the uneven distribution of skill endowments across states contributed to the divergence in state incomes. However, skill endowments continued to converge across states. Higher rates of educational acquisition in the poorer states counterbalanced the rise in skill prices. While changes in the prices of skills explained almost one-half of the increase in state income inequality, changes in quantities of skills accounted for a one-third reduction in such income variability across Mexican states. This implies that unobserved changes in skill prices and quantities and other unobservable factors accounted for most of the Mexican economic divergence.

In addition to the rising skill premium and the uneven distribution of educational levels, other demand-related factors appear to have favored the richer states. The reduction of tariffs that protected the agricultural sector and the virtual dismantle of subsidies and public credits led to rapid declines in agricultural prices and employment. Consequently, poorer states specialized in agricultural production declined during the last decade. The elimination of trade restrictions and foreign investment controls and the economic boom in the U.S. greatly increased exports, and FDI inflows favored rich states located close to the U.S. border. All skilled and unskilled workers in the manufacturing-intensive states in the North, with location advantages to the U.S. market, experienced relatively larger increases in wages during the 1990s. Using state-level regressions, I find that states with larger initial flows of FDI and lower shares of agricultural employment, and which are located closer to the U.S. performed better. Public infrastructure and state FDI flows are highly correlated and it is impossible to separate the effects of these variables. While border states may have benefited from liberalization by attracting more foreign capital and by the shift of Mexican manufacturing from central Mexico to the North, I find no evidence for the claim that skill demand increased rapidly in this region or that this region attracted more human capital relative to other regions. 


\section{NOTES}

1. After forty or more years of import substitution policies and an external sector limited to crude oil exports, the collapse of international oil prices and the peso crisis of 1982 forced Mexico to open its market to international competition. The first attempt by Mexico to open the economy occurred in the mid-1980s with its inclusion in the General Agreement on Tariffs and Trade and a unilateral reduction in tariffs and quotas. The necessity of finding a new way to grow led the country to participate, one decade later, in the largest free-trade area of the world, the North American Free Trade Agreement. At the same time, domestic reforms such as privatizing state-owned enterprises; assigning property rights to former communal lands; establishing autonomy of the central bank; opening capital markets, allowing foreign direct investment and repatriation of profits; reducing the value added tax; and containing union power modified the production structure of the economy.

2. The adoption of trade liberalization and other market-oriented reforms impacted the wage structure in Mexico by increasing inequality and education premiums. Feenstra and Hanson (1997) claim that wage differentials had increased over time, but this process began well before trade liberalization. Harrison and Hanson (1999) argue that wage inequality in Mexico declined in the decades prior to the trade reform but rose after it. Feliciano (2001) claims that wage dispersion increased right after trade liberalization. And Airola and Juhn (2003) explain that wage inequality increased sharply during 1984-1994 but has remained unchanged since that time.

3. It is interesting to note that during the $1990 \mathrm{~s}$, average real wages decreased in all states but decreased less in the richer states. A thorough examination of why real wages decreased is beyond the scope of this article. One conventional explanation is the inflation that followed the peso devaluation of December 1994 (Hanson 2005). Other possible explanations are the rapid growth of the labor force during this period, the decline of union power, and the agricultural reforms that decreased real agricultural prices.

4. Unfortunately, there is no official gross state product (GSP) data before 1970. I use the original estimates provided by Appendini (1978) and used by Esquivel (1999). For 1970 to 2000, I employed the official series from the Mexican Institute of Statistics (INEGI), which provides state level output data every five years from 1970 to 1985 and annual data from 1993 to 2000 .

5. The $\beta$-convergence is a necessary but insufficient condition to establish absolute change in dispersion (or absolute convergence/divergence) while $\sigma$-convergence is a sufficient condition (Quah 1993). The $\beta$-convergence is a sufficient condition to establish relative change in dispersion (or relative convergence/divergence) between regions. Absolute change in dispersion measures only the change in the variance of the observations while relative change in dispersion considers the change in the mean of the observations.

6. Campeche and Tabasco are the main producers of crude oil in Mexico and their GSP values are overestimated. Oil in Mexico is owned by the federal government and profits from the extraction of crude oil in such states go directly to the federal government.

7. The Mexican Economic Censuses (EC) of 1988, 1993, 1998, and 2003 provide state-level data on value added and payments to employees. The GSP in Mexico is calculated by the Value Added (VA) method. Hence, GSP and VA from the economic censuses must follow similar patterns. However, the EC does not survey over half of the national production. It does not include the primary sector (agriculture, livestock, and forestry), government, production of non- 


\section{GROWTH AND CHANGE, JUNE 2006}

fixed-location businesses (street shops, taxi drivers, housekeepers, etc.), self-consumption, and households' production (in the year 2000, the share of households' production was 35 percent of national gross domestic product [GDP]). In addition, state VA of the construction, transport, and financial services sectors are assigned to the state where the firms' headquarters are located and not where production takes place. As a result of the incomplete coverage of the EC and inconsistencies in the data, state VA reported in the EC converged between 1988 and 2003. This result must imply a very strong state divergence in agriculture and households' VA. From 1993 to 2003, the national sum of GSP per capita (in real terms) grew by 12 percent, while the national sum of the economic census' VA per capita (in real terms) grew by 25 percent. The VA from the EC represented 37 percent of national production in 1993 and 41 percent in 2003. This must imply a significant growth of the "formal" production in Mexico.

8. Statistical inferences are significant at the state level because of large sample sizes, unlike the Mexican Households Income-Expenditure Survey (ENIGH). In addition, the Population Census data sets are nationally representative, unlike the National Survey of Urban Employment (ENEU), which covers only large urban areas.

9. Notice that SLE per capita data goes from 1990 to 2000, while GSP per capita data goes from 1985 to 2000.

10. With regard to the compatibility of the Mexican System of National Accounts (MSNA) and Mexican Population Census (MPC), Mexico's GDP per capita in 1990 was 40,280 pesos $(\approx \$ 4,260$ U.S.) (http://www.ocde.org), while labor earnings per capita in 1990 (using the MPC data) were 12,504 pesos $(\approx \$ 1,350)$. Labor earnings per capita represented 31.7 percent of GDP per capita in that year. On the other hand, "Payments to Employees," the name given to labor earnings on the MSNA, represented 30 percent of the GDP in 1990 and 31 percent in 2000 (source: http://www.inegi.gob.mx). Notice also that "Payment to Employees" in Mexico is considerably smaller than in other countries, like the U.S. where it comprises almost two-thirds of the GDP share.

11. The workers are all individuals who report positive labor earnings. When calculating SLE per worker, I consider only those workers who worked at least half-time (thirty hours a week) and earned at least half minimum wage (two pesos per hour). Working age population is defined as all individuals between sixteen and sixty-four years old.

12. Revenga (1997), Feenstra and Hanson (1997), Hanson (1997, 2003), Feliciano (2001), Cragg and Epelbaum (1996), Szekely (1998), Airola and Juhn (2003).

13. Convergence in adult population education is also observed across Mexican states.

14. The $\beta$-convergence estimate of education is obtained by regressing the change on mean education levels against the initial level of state wages: $\left(\mathrm{EDU}_{2000}-\mathrm{EDU}_{1990}\right)=\alpha+\beta \ln \left(\right.$ wage $\left._{1990}\right)$.

15. As shown in Table 3, other population characteristics are also converging across Mexican states.

16. Note that the price effect here refers to the economy-wide change in skill prices, as the estimates, $\gamma_{0}$ and $\gamma_{1}$, do not vary by state. If returns to skills rose differentially across states, these differences would be absorbed in the residual term. To what extent did differential increases in the skill "price" account for the divergence in state wages? Independent $\gamma$-estimates (skill premiums) for education, experience, and gender for every state of Mexico in 1990 and 2000 show that while returns to skills did rise by different amounts across states, there is no systematic relationship between the rise in skill premiums and initial wage or skill levels. These estimates suggest that the differential changes in the skill premiums are not the culprit behind the divergence in state incomes. 
17. The same analysis can be done in a different order (i.e., allowing first state skill endowments to vary, and attributing changes in skill prices to additional changes in state inequality in $\left.\ln \left(\hat{Y}_{s, 00}^{P Q}\right)\right)$ and would simply rearrange the assignment of interaction terms.

18. One can go forward and decompose the equation (4) price and quantity effects into each one of the measures of skills: education, experience, and gender. For example, the predicted wage for 2000 allowing only the education premium to vary but keeping everything else at the 1990 level is defined as $\ln \left(Y_{s, 00}^{P, E D U}\right)=\gamma_{00}^{E D U} E D U_{s, 90}+\gamma_{90}^{E X P} E X P_{s, 90}+\gamma_{90}^{E X P^{2}} E X P_{s, 90}^{2}+\gamma_{90}^{G E N} G E N_{s, 90}+v_{s, 90}$. Predicted wages for 2000 allowing other skill prices or state skill endowments to change but keeping fixed everything else are calculated similarly. Table 4 also displays decomposition results by measure of skill. The variance of $\ln \left(\hat{Y}_{s, 00}^{P, E D U}\right)$, allowing only the education premium to change, increased by 0.009 , accounting for 40 percent of the increase in the variance of state wages. The education quantity effect accounts for a 50-percent reduction in the variance of wages. The experience price and quantity effects account for 6 percent and 31 percent of the increase in the variance of state wages, respectively.

19. The initial year must be 1990; however, the first available year of FDI data at the state level was 1994.

20. Foreign direct investment increased from 10.7 billion dollars, or 2.5 percent of the Mexican GDP in 1994, to 16.4 billion dollars, or 2.8 percent of the GDP in 2000. Similarly, international trade increased from 42.7 billion dollars, or 13.6 percent of the GDP in 1991, to 166.5 billion dollars, or 28.7 percent of the GDP in 2000 .

21. In 1994, the Federal District received 39.6 percent of all FDI flows to the country, followed by 32.6 percent to the border region. In 2000, the border region hoarded 46.2 percent of all FDI flows to Mexico and the Federal District only 24.2 percent.

22. At the national level, the postpreparatory wage ratio, defined as the average wage of workers with twelve or more years of schooling divided by the average wage of workers with up to eleven years of schooling, increased by 13 percent from 1990 to 2000. However, at the border region, this ratio decreased by 1.5 percent.

23. Some 7.6 percent of all workers in the border region are interregional migrants while at the national level, this number is 4.3 percent.

24. For a precise review of the effect of skilled biased technical change on the relative demands for skilled and unskilled labor, relative wages, and wage-bill shares, see Acemoglu (2002), especially pages $18-23$.

\section{REFERENCES}

Acemoglu, D. 2002. Technical change, inequality, and the labor market. Journal of Economic Literature 40(1): 7-72.

Airola, J., and C. Juhn. 2003. Wage inequality in post-reform. Mexico. Unpublished manuscript. University of Houston.

Appendini, K.A. 1978. Producto interno bruto por Entidades Federativas 1900, 1940, 1950 y 1960. Unpublished paper. El Colegio de Mexico.

Aroca, P., M. Bosch, and W.F. Maloney. 2003. Is NAFTA polarizing Mexico? Or existe tambien el sur? Spatial dimensions of Mexico's post-liberalization growth. Unpublished paper. Universidad Catolica de Chile.

Barro, R.J., and X. Sala-i-Martin. 1991. Convergence across states and regions. Brookings Papers on Economic Activity 1: 107-158. 


\section{GROWTH AND CHANGE, JUNE 2006}

1992. Convergence. Journal of Political Economy 100(2): 223-251.

Blau, F.D., and L.M. Kahn. 1997. Swimming upstream: Trends in the gender wage differential in the 1980s. Journal of Labor Economics 15(1): 1-42.

Chiquiar, D. 2002. Why Mexico's regional income convergence broke down? Unpublished paper. University of California, San Diego.

Cragg, M.I., and M. Epelbaum. 1996. Why has wage dispersion grown in Mexico? Is it the incidence of reforms or the growing demand for skills? Journal of Development Economics 51: 99-116.

Esquivel, G. 1999. Convergencia regional en Mexico. El Trimestre Economico 1940-1995 66(4): $725-761$.

Esquivel, G., and M. Messmacher. 2002. Sources of regional (non) convergence in Mexico. Unpublished paper. El Colegio de Mexico.

Feenstro, R.C., and Gordon H. Hanson. 1997. Foreign direct investment and relative wages: Evidence from Mexico's maquiladoras. Journal of International Economics 42: 371-393.

2002. Why NAFTA did not reach the south. Unpublished paper. El Colegio de Mexico.

Feliciano, Z.M. 2001. Workers and trade liberalization: The impact of trade reforms in Mexico on wages and employment. Industrial and Labor Relations Review 55(1): 95-115.

Hanson, G.H. 1997. Increasing returns, trade and the regional structure of wages. The Economic Journal 107: 113-133.

1998. Regional adjustment to trade liberalization. Regional Science and Urban Economics 28: 419-444.

- 2004. What has happened to wages in Mexico since NAFTA? Implications for Hemispheric free trade. In Intergrating the Americas: FTAA and beyond, 505-537. Cambridge: Harvard University Press.

- 2005. Globalization, labor income and poverty in Mexico. NBER Working Paper 11027.

Hanson, G.H., and A. Harrison. 1999. Trade liberalization and wage inequality in Mexico. Industrial and Labor Relations Review 52(2): 271-288.

Harrison, A., and G.H. Hanson. 1999. Who gains from trade reform? Some remaining puzzles. Journal of Development Economics 59: 125-154.

INEGI, Instituto Nacional de Estadistica, Geografia e Informatica. Censos de Poblacion y Vivienda 1990 y 2000 and Banco de Información Economica. http://www.inegi.gob.mx. Censos Económi$\cos 1988,1993,1998$ y 2003. http://www.inegn.gob.mv. Anuano Estadistico de los Estados Unidos Mexicanos. Edición 1991.

Juan-Ramon, H., and L.A. Rivera-Batiz. 1996. Regional growth in Mexico: 1970-1993. IMF Working Paper No. 25.

Juhn, C., K.M. Murphy, and B. Pierce. 1993. Wage inequality and the rise in returns to skills. Journal of Political Economy 101(3): 410-442.

Krugman, P., and R.L. Elizondo. 1996. Trade policy and the third world metropolis. Journal of Development Economics 49(1): 137-150.

Mallick, R., and E.G. Carayannis. 1994. Regional economic convergence in Mexico: An analysis by industry. Growth and Change 25: 325-334.

Messmacher, L.M. 2000. Desigualdad regional en Mexico. El efecto del TLCAN y otras reformas estructurales. Banco de Mexico. Documento De Investigación No. 2000-4.

Quah, D. 1993. Empirical cross-section dynamics in economic growth. European Economic Review 37(2): 426-434. 
Revenga, A. 1997. Employment and wage effects of trade liberalization: The case of Mexican manufacturing. Journal of Labor Economics 15(3): S20-S43.

Sanchez-Reaza, J., and A. Rodriguez-Pose. 2002. The impact of trade liberalization on regional disparities in Mexico. Growth and Change 33: 72-90.

Solow, R.M. 1956. A contribution to the theory of economic growth. Quarterly Journal of Economics 70(1): 65-94.

Szekely, M. 1998. The economics of poverty, inequality and wealth accumulation in Mexico. St. Antony's Series. New York: St. Martins Press: London: MacMillan Press in association with St. Antony's College. 